Article

\title{
Pastoralism in Latin America: An Ensemble of Religious Governmental Technologies in Colonial Costa Rica
}

\author{
Edgar Zavala-Pelayo
}

Institute of Latin American Studies, Stockholm University, 10691 Stockholm, Sweden; ezpelayo@gmail.com

Received: 29 May 2018; Accepted: 26 June 2018; Published: 28 June 2018

\begin{abstract}
Based on a critical empirical application of Foucault's concept of pastoralism and a genealogical research approach, this article suggests that the Catholic regime that operated in Costa Rica during the Spanish colonial period (16th to 19th centuries), developed an ensemble of distinctive 'technologies of government' - charity, ceremonial strictness, bio-political control, geo-political rule, and administrative efficiency. Drawing on documentary and archival material, the analysis highlights both the governmental 'logics' and the governmental 'techniques' of the above technologies, as well as their complex centuries-long operation. The conclusions remark how such a complex ensemble of religious governmental technologies problematizes the synchronicistic and reductionist analyses of religion and politics; historical-institutionalist studies of colonial Catholicism in Latin America; and the compartmentalization of sovereignty, discipline, and apparatuses of security that Foucault originally proposed to account for the historical development of governmentality.
\end{abstract}

Keywords: bio-politics; Catholicism; Costa Rica; economic thought; genealogy; geo-politics; governmentality; pastoralism; technologies of government

\section{Introduction}

Despite its geographical comparative relevance in fields such as welfare economics and democratic development (cf. Gutierrez-Haces 1987; Booth et al. 2010), Costa Rica might not stand out as a salient case of (Catholic) religious government in Central America from a historical perspective. Firstly, Costa Rica was the last province the Spanish and the Catholic regimes colonized in this isthmian region (Gutierrez-Haces 1987; Pinto 1993). Secondly, except for the Franciscans' convents, the city of Cartago's main parish and a network of rural 'doctrinas', no grandiose institutional machinery of a religious nature was built in Costa Rica (Picado 1985c). The institutional seat of the Catholic regime in Central America, including a tribunal of the much discussed Holy Inquisition (Chinchilla 1953), was indeed in the captaincy of Guatemala's bishopric, overseen in turn by Mexico City's archbishopric further up north ${ }^{1}$. Thirdly, the indigenous population that experienced first-hand the Spanish Catholic regime of evangelization-government, discussed below, was not in the hundreds of thousands as in the densely populated Mayan regions of Central America; some authors even claim that the Indigenous population in Costa Rica was "almost destroyed"2 by the end of the 16th century (Pinto 1993, p. 40). From such a historical-institutional perspective, the case of Costa Rica may well represent a secondary case in Central America's religious field. This paper, however, does not draw on a historical-institutional

1 From 1750 to 1850 Costa Rica's religious affairs were overseen by the Nicaragua and Costa Rica bishopric, with its seat in Leon, Nicaragua (Velazquez 2011, pp. 570-71).

2 This quote was translated by myself; unless otherwise stated, the citations from works originally published in Spanish are my translations. 
view of religions, but on a critical Foucauldian-governmentality approach to religions, which makes the apparently irrelevant case of Costa Rica a particularly relevant analytical subject.

In addition to a critical use of Foucault's original concepts, a Foucauldian approach to religions entails a de-centering of some theoretical and methodological conventions. Firstly, a Foucauldian approach to religions requires the analyst to conceive of religions not only as sporadic and/or systematic interventions in the governmental (secular) apparatus of the state, but religions as an operational governmental structure per se-or, as I suggest in this paper, a complex ensemble of technologies of government, that cannot be reduced to the Church's institutional policies. This de-centering also requires the analyst to put aside secular(istic) institutional views of social reality that tend both to separate aprioristically "the religious" from "the secular" and to reduce the complex intertwining between religions and government as a relatively clear-cut matter of "church/es (the religious) and the state (the secular)" (Golder 2007). Secondly, a Foucauldian theoretical-methodological approach to religions is not primarily concerned, indeed, about the establishment and consolidation of churches, monasteries, and other (material) religious institutions, but rather focuses on the 'meta-institutional' (Foucault 2007, pp. 117, 191-92) configuration and display of the technical (practical) and epistemic (discursive) bases (Saar 2011) upon which the governmental functions (i.e., governmental technologies) of religions develop. In that sense, for instance, the seat of the Holy Inquisition in colonial Guatemala is as relevant as the practices and discourses deployed by Inquisitors and other related agents during their inquisitional activities in Costa Rica. Regarding governed and governing agents, the religious technologies of government that are discussed below, were doubtless applied forcefully to an indigenous population whose size was significantly reduced over the centuries. However, the indigenous population in Costa Rica was not entirely annihilated ${ }^{3}$ and, more importantly, just as it is impossible to assert that Catholicism disappeared from Costa Rica as the indigenous population declined, it would be entirely misleading to presuppose that the governmental technologies, put forth below, ceased their operation after a segment of such an indigenous population began its transformation into Costa Rica's creole population-a growing demographic group upon which the Catholic governmental discourses and practices continued to operate. In fact, some of the governmental technologies and their operational components, discussed below (for instance, the 'technology of bio-political control' and its 'community surveillance' of sexual bodies), also involved the active participation of, and the control over, the Spanish population living in this province. All in all, the case of colonial Costa Rica is highly suitable and particularly significant to understand, precisely, the diachronic pervasiveness and centuries-lasting saliency of religions as meta-institutional technologies of government; technologies that, on the one hand, operate in association with religious institutions, yet on the other hand, develop and run largely through actions- and discourse-based societal and individual patterns with both a changing nature and a considerable 'long-durée'.

3 The generalist historiography in Costa Rica tends to portray the indigenous population trend in the colonial period as a trend of obvious decline and virtual annihilation. According to Pinto's miscellaneous sources (1993, pp. 80-81) whereas there were 400,000 indigenous inhabitants in the Province of Costa Rica in 1492, the same population amounted only to 70,000 inhabitants in 1569; and to 1000 in 1800 (1993, p. 81). More specialized analyses, however, portray a different scenario. Like Pinto (1993), Fonseca (1983) also notes the significant decrease of the indigenous population during the early decades of violent colonization (1520-1560). However, Fonseca notes that the indigenous population of Costa Rica in 1522, amounted to only 27,200 individuals (1983, p. 39) and, despite the ensuing decline, it amounted to 17, 500 inhabitants in 1569 and 14,900 individuals in 1611. For Fonseca the indigenous population continued its reduction up until the 19th century (1983, p. 35); however, it also "reached a stability between 1778 and 1801" (1983, p. 38). Although the colonial Catholic Church's evangelizing-governmental agenda make the reports of this institutions biased to a greater or lesser extent, its internal sources point a demographic landscape that fits in Fonseca's. In a statistical report published in 1900, bishop of Costa Rica Bernardo A. Thiel (1902, p. 5) noted that the "Indians of pure race" in Costa Rica amounted to 8281 individuals in 1801; in other words, they represented $17 \%$ of the total population in Costa Rica in the early 19th century. 
To develop the above approach, and to contribute to the understanding of the contemporary religious dimension ${ }^{4}$ of the only confessional (Catholic) state in Latin America ${ }^{5}$, the section below summarizes Foucault's concept of, and the theoretical perspective behind, governmentality and pastoralism. The third section introduces the genealogical (theory-)method that was adopted, and the archival data that was collected and analyzed. The fourth section presents a genealogy of pastoralism in Costa Rica, that is, an analysis of Catholicism as a governmental regime that developed a complex "ensemble" (Hearn 2008, p. 47) of 'governmental technologies' during the Spanish colonial period, from the mid-16th century to the early 19th century-charity, ceremonial strictness, bio-political control, geo-political rule, and administrative efficiency. The specific 'logics' and 'techniques' of each technology are also discussed. The differential combination, diachronic transformations of, and resistances to these technologies are explored. The conclusions remark how these religious governmental technologies problematize the synchronicistic and reductionist analyses of religion and politics, the historical-institutional and Foucauldian analyses of colonial Catholicism in Latin America, and the "triangle" of "sovereignty, discipline, and governmental management" (Foucault 2007, p. 107) that Foucault originally proposed, to account for the historical development of governmentality.

\section{Governmentality and Pastoralism}

In a concise form, governmentality can be defined as the exercise of "government" upon individuals and collectivities through both "governmental apparatuses" and "a series of knowledges" (Foucault 2007, p. 108)—or "material" and "epistemic" (Saar 2011, p. 39) mechanisms—that experience resistances or counter-conducts (Foucault 2007, pp. 201-16; see also Chrulew 2014; Golder 2007), as well as ruptures and continuities over history. Governmentality also means a different theoretical-analytical perspective (Dean 2010; Foucault 1977a) to analyze states, government, and governance in contemporary societies. It is an analytical lens that avoids traditional state-centric normative positionings (Foucault 2007, pp. 117-18) and conceives the power of modern states as rooted in epistemic and material foundations, located beyond the strictly political field (Bröckling et al. 2011), and working through both technologies of external domination and "self-technologies", or the instilled mechanisms "through which the self is constructed or modified by himself" (Foucault 1993, p. 204; Golder 2007, p. 161). Foucault located such extra-political epistemic and material foundations of the modern state in different historical formations, which include 18th century political economy, liberalism and neoliberalism (Foucault 2008), the military model, the early concept of police, and the "Christian pastorate" (Foucault 2007, p. 145). It can be said indeed that Foucault's attention to religion goes from observing religion, namely specific Christian rites like the confession, in the context of bio-political strategies and apparatuses of health regulations (Foucault 2003) and sexual control (Foucault 1978), to conceiving religious discourses and practices as a "pastoral" governmental model that

4 Results from a recent survey (Araya 2017) suggest that 72\% of the Costa Rican population is nominally Catholic; $12.3 \%$ affiliates to Evangelical and Pentecostal churches; $10.4 \%$ affiliates to traditional/historical Protestant Churches and $10.4 \%$ "does not profess a religion" $(2017$, n.p.). Moreover, this survey also points that $60 \%$ of the surveyed sample support the confessionality of the Costa Rican state and $25 \%$ think this must be reformed.

5 Whereas liberal political forces have been part of Costa Rica's political arena since the early 19th century (Arguedas Ramírez 2010; Mora 1992; Silva 1991; Rodríguez 2014), and some secular reforms have terminated the civic-administrative jurisdiction of the Catholic Church-e.g., the registry of births and marriages—-the article 75 in Costa Rica's constitution dictates that the religion of the state is "[t]he Roman, Catholic, Apostolic Religion", to which the state "contributes [ ... ], without restricting the free exercise of other cults that oppose neither to universal morals nor to the good customs". (N.a. 1996, p. 431). Although the above does not translate into a theocratic state, the Catholic Church in Costa Rica has had a central position in the country's societal and political dimensions. The Costa Rican state and the Catholic Church have "set frameworks for negotiations and agreements" (Maroto 2014, p. 291), including political support from the latter to the former and economic support from the former to the latter through direct funding, or indirect benefits such as tax exemptions and pensions for retired priests. The growing Christian minorities are recently adding another layer of complexity to Costa Rica's religious field and its religious-governmental intertwinings-as elsewhere in Latin America (Aragon 2014; Cordoba 2014; Freston 2013; Jones and Cunial 2017). 
has co-constituted both modern governmentality/ies and the subjectivity of individuals (Foucault 1983, 2007, 2011, 2014).

Foucault described pastoralism as a governmental model that can be traced back to the ancient Greek and Hebrew pastoral archetypes, and acquires its most decisive configuration from the rather monastic (Zavala-Pelayo 2016a), European Christianity. It is a governmental model based on the role of the Christian pastor in relation to his "flock". Its main characteristic is a discursive and practical deployment of an other-worldly salvation as a strategic governmental teleology (Foucault 2007, pp. 166-67; Foucault 1983, p. 214). This pastoralism also developed and deployed a series of governmental principles, or simultaneously pragmatic and teologico-epistemic strategies of government. For instance, a "reciprocal responsibility", or the community's responsibility for having a good destiny and the pastor's permanent responsibility for the whole community (Foucault 2007, p. 168); an "analytical responsibility", or the pastor's obligation to know "everything that every single sheep has done" (Foucault 2007, p. 170); a "transferability" that made the faults and good deeds of the flock to be considered the shepherd's as well; a "sacrificial reversal" or the pastor's acceptance of risking his own life to save his flock; and an "alternate correspondence" or the desirability of the pastor's virtuous actions and weaknesses for the sake of "the edification of his sheep" (Foucault 2007, pp. 170-85). In other works, Foucault highlights the relatively agentic self-technologies of pastoralism, such as the reflexive production of truth by a subject who not only has to know and assess his or her "faults" (Foucault 1993, p. 211), but also has to speak out those faults and the resulting self-analysis in a confessional setting (Foucault 2014). In this view, monastic European Christianity also contributed to the development of an individual permanent obedience to a spiritual master, a governmental mechanism that, together with the confessional self-production of truth, Foucault qualifies as the background of "Western subjectivity" (Foucault 2014, p. 285)—a topic I will return to in some of the section below.

The principles above did not remain unchallenged. Foucault discusses a series of "counterconducts" (Foucault 2007, p. 201; see also Chrulew 2014) that disputed practically and theologically the aforementioned ways of government and self-government, and were taken up by the 16th century Protestant Reformers. Those counter-conducts included the medieval practices of ascetism, which dispensed with the need of external authority; the challenges to the pastor's original attributions in Christian communities like the Hussites and Anabaptists; the autonomous self-guidance of mysticism; and the return to the scriptures, whose inherent primacy rendered pastoral intervention useless (Foucault 2007, pp. 204-16). Challenged by these organized counter-conducts, Christian pastoralism thrived nonetheless and became, in Foucault's words, the "threshold of the modern state" (Foucault 2007, p. 165).

Studies that address Foucauldian pastoralism and use it to analyze social or political phenomena can be catalogued into nominal, theoretical, and theoretical-empirical types. Nominal studies use the concept of pastoralism only as a primary or secondary descriptor of phenomena, generally without a discussion of the concept's genealogy (e.g., Bejerot and Hasselbladh 2011; Mayes 2009; Tierney 2004). Theoretical studies expand, critically or exegetically, on Foucault's pastoralism by revisiting Foucault's theorizations (e.g., Carrette 2000), or by drawing on alternative theological sources (e.g., Chrulew 2013; Siisiäinen 2015). Theoretical-empirical studies of pastoralism address the concept drawing on alternative religious traditions as well as specific empirical cases from past or present societies (Curtis 2017; Mutch 2017; Petterson 2014; Villadsen 2007). Petterson (2014), for instance, analyzes the pastoral power of a Protestant variety mobilized by Danish Lutheran missionaries in Greenland from the 18th century onwards. The author suggests that such a colonial Protestant pastoralism re-structured rather successfully Greenlandic society through governmental techniques such as writing. Drawing on the Scottish Protestant tradition, Mutch (2017) discusses a Presbyterian pastoral power that developed systematic governmental "practices" (Mutch 2017, p. 85), such as the examination and self-examination of conduct, accountability and record keeping, an emphasis on ecclesiology, and the value of thorough organization. To shed light on both the genealogy and the contemporary presence of pastoralisms beyond "the West/s", I have adopted a theoretical-empirical 
approach to investigate pastoralism as religious technologies of government in Mexico. I have argued that the colonial pastoralism in Mexico (16th-18th centuries) might have deployed Foucault's principle of analytical responsibility, but it consisted of different governmental logics and techniques of a biopolitical nature, that included an integralist (realist and transcendental) salvationist teleology (Zavala-Pelayo 2016b), as well as a charitable humility, a performative correctness, and a ceremonial strictness (Zavala-Pelayo 2016a)— topics that will be addressed in one of the sections below.

\section{Methodology}

Critical and exegetical authors who have addressed Foucault's methodological strategies tend to agree on what Foucault's archaeological method entails, but tend to differ on the definition of the latter's successor, the genealogy. For instance, whereas Carrette (2000, p. 18) asserts that the genealogical methodology studies the "appearance, growth and variation" in discourse formation as well as "the 'deployment' of discourse", Garland (2014, p. 372) points that the genealogy traces the "struggles, conflicts, alliances, and exercises" out of which "contemporary practices and institutions emerged". These and other authors' (e.g., Behrent 2012, p. 157) relative divergence on Foucault's genealogical method is understandable. Foucault's dedicated account of the genealogical method (Foucault 1977a) reads more like a review of Nietzsche's philosophical stance towards the study of morals and a theoretical account of why such Nietzchean genealogy is relevant, than a precise description of what the genealogical method comprises. More concise forms of his genealogical approach (Foucault 2007, pp. 116-19) also boil down to theoretical-perspectival tenets. All in all, Foucault's genealogical positioning is consistent, a genealogy is not a search of chronological origins, it is not a normative inquiry about the truth of historical events (Foucault 1977a); it is not a study of the putative object and function of institutions either (Foucault 2007, pp. 117-18). The genealogy is instead a "historico-philosophical" (Takács 2004, p. 871) analysis of the non-evident "material and epistemic" foundations (Saar 2011, p. 39) upon which the present and its institutions emerged. The genealogical analysis of the modern state, for instance, amounts to a search of the pre-modern, and not necessarily political, ensembles of procedural, technical, normative, and material components, whose tensions and interactions over the centuries formed modern states. To apply this theoretical-methodological approach to the context of colonial Costa Rica and the pastoral technologies developed there, additional guidelines were necessary.

Instead of attempting a genealogical analysis by tracing "accidents" or "systematic dissociations" (Foucault 1977a, pp. 144, 164) in the religious history of Costa Rica, the genealogical analysis below consisted of a tracing of patterns in governmental and disciplinary discourses (Foucault 1977a, pp. 140-43; Carrette 2000) and practices (Foucault 1977a, pp. 146-52; Dean 2010; Garland 2014), observable in colonial documents authored by religious agents in Costa Rica, or writing about Costa Rica, during the Spanish colonial period. Governmental principles, or "technologies" of government and self-government (Foucault 1993, p. 204), were then inferred inductively through a 2-levels reading of the material, literal and interpretive-theoretically informed (Mason 2002), and the resulting iterative coding of patterns. The set of documents included religious constitutions and rules, letters of bishops and friars to the king and to royal and religious authorities, and reports by missionaries and bishops. The materials were collected from two sources, compendiums by Costa Rican historians published in the late 19th century and early 20th century, and the electronic repository of the 'Archivo General de Indias', the Seville-based Spanish archive that houses colonial-era documents from the Americas and the Philippines ${ }^{6}$.

To reduce the risk of selection bias (Carrette 2000, pp. 50-53, 134), without compromising the critical and non-teleological nature of the genealogical approach, evidence of both the actual application

6 The majority of documents from the second source were retrieved from the 'Audiencia de Guatemala' folder; additional documents were retrieved by searching specific terms (e.g., Costa Rica, Nicoya, Cartago) through the Archive's search engine. 
of, and resistances to, the aforementioned governmental technologies were sought, not only in the same documents by religious agents, but also in the available documents authored by civil authorities ${ }^{7}$ and lay Spanish, creole, and Indigenous individuals ${ }^{8}$. Contemporary historiographical works by both religious and non-religious authors on colonial Costa Rica were also consulted to confirm the above discourses and add nuances and secondary data where necessary.

\section{The Technologies of Charity and Ceremonial Strictness}

The governmental charity and ceremonial strictness that can be observed in Mexico's colonial pastoralism (Zavala-Pelayo 2016a) were also active governmental technologies in colonial Costa Rica. Charity was not only a matter of religious virtues (Pansters 2012, pp. 46-47), but also a governmental matter. Catholic charity was an operational and strategical principle of (self)government, whether deployed by Franciscans (Picado 1985a, p. 74), diocesan priests, or from lay individual to lay individual. As the bishop in charge of Costa Rica's colonial territories in the early 17th century argues, "Indians are docile people [ ... ] and by treating them with charity and love, they will be good Christians" (in Fernandez 1886, p. 143). As in colonial Mexico, two types of governmental charity are distinguishable in primary and secondary sources. The first type is an asymmetric type of charity deliberately exercised by the priest upon the Natives or the lay individual. According to a document written by Franciscan friars in the second half of the 16th century, Juan de Estrada y Rávago- "the first discoverer" of Costa Rica-" "generously spent his money helping these [Native] people and giving them gifts, so to attract them to listen to God's words and his doctrine" (in Peralta 1883, p. 457). Similarly, at the end of the 17th century, a group of Franciscan friars state in a report that they "have learnt that using the love, kindness, and charity" they preached about "is appropriate for them [Natives] to embrace perfectly the things of our holy faith" (in Fernandez 1886, pp. 389-90) . $^{9}$

In addition to this asymmetric charity, a 'symmetric' or less vertical charity was (expected to be) deployed from lay to lay individual (Zavala-Pelayo 2017, pp. 815-16). The discourses of this modality can be inferred from Catechisms and its practices can be verified in the communitarian assistential practices of the 'cofradía'. According to the catechism authored by Franciscan friars Torres and one of the "founders of the [Catholic] Church in Costa Rica" (Picado 1985a, p. 74), friar Betanzos, charity is the virtue that defeats the capital sin "envy" and "him who is in charity is with God", hence "we shall remain always in God" (Torres and Betanzos 1905, pp. 77-78). The practice of such a horizontal charity can be observed in Costa Rican 'cofradias'. As in 'cofradias' elsewhere in colonial Latin America (Zavala-Pelayo 2016a, p. 187), these organizations in Costa Rica deployed charity for both this and the after world. They functioned as credit and pension institutions for the living (Hernández and Villanueva 2011; Jerez-Brenes 2016). Masses and prayers for the living, and the deceased members' transit to heaven after death (Jerez-Brenes 2016; Quiros 2013, p. 21; Velazquez 2013), were also offered by 'cofradias', after a properly charitable "alm" (Quiros 2013, p. 20) was given to a local priest who conducted the rituals. 'Cofradias' were also frequent recipients of the assets, donated through the wills of deceased members (Velazquez 2013, p. 199). In her archival analysis of eleven Indigenous 'cofradias in the Northwestern region of Nicoya, Quiros notes that a "communitarian sense", as well as "reciprocity and solidarity" were principles highlighted and stated in all the organizations' 'ordenanzas' (Quiros 2013, p. 23). These principles and services, however, were not exclusively "pious" (Jerez-Brenes 2016, p. 65). It is safe to argue that 'cofradias" charitable practices turned the tenet of

7 e.g., royal edicts, letters by the king or governors to Bishops or friars, co-authored letters by members of Cabildos (city councils).

8 e.g., letters by encomenderos; suits by Spanish settlers against local caciques; "merits and services" documents or Probanzas by different witnesses on Lay Individuals.

9 The humbleness that is evident in the case of colonial Mexico (Self-Reference 2) was, however, not observed in the documentary material from Costa Rica. It is likely that humbleness was not considered necessary in a comparatively smaller region that to some extent lacked the complex political and societal institutions that the Spanish conquistadores and evangelizers found in Central and Southern Mexico. 
being charitable towards each other into a self-technology of government that enabled individuals to conceive themselves as agentic subjects (Foucault 1993, pp. 203-4) within a relatively "autonomous" organization (Hidalgo 2013, p. 41; see also Quiros 2013, pp. 8-9), while reinforcing the naturalness and indirect oppression of the asymmetric charity exercised by the Catholic regime.

The evidence suggests that ceremonial strictness was systematically used as governmental procedure in Costa Rica as well. As in colonial Mexico, the aim of this technique was for the government of individuals and community life through the (governmental) demand of a rigorous, intensive, and "meticulous" (Foucault 1977b, p. 50) fulfillment of the Church's religious rituals and their external requirements-doubtless the cause and consequence of the "external, formal, and routine" Catholicism that Picado (1985b, p. 142) notes ${ }^{10}$. Hence, "clothing, wine, oil, ornaments" as well as "books of chants, Catechisms, missals" (in Peralta 1883, pp. 604-5) and other religious textbooks, were among the items urgently requested in the 1580s by Cartago's Franciscan friars to their superior, for the proper operation of their convent. The fulfillment of ceremonial strictness was also the reason the superior of Cartago's parish complains in the second half of the 18th century about the lack of "decency of ornaments" (in Gonzalez 1902, p. 33) in one of the city's 'cofradias'. It was not only that Catholic rituals and their required items and ornaments had to be properly in place, they also had to be appropriately cared or utilized by both the priest and the believer. Hence the dramatic and specific statements of friar Escurra in the early 18th century, on how the Natives who resisted evangelization in the southern region of Talamanca destroyed churches, "took away all the ornaments, and, what most hurts our hearts, burnt the figures of the saints, even that of Christ our Lord and the Holy Mary" (in Fernandez 1886, p. 464).

In addition to the technologies of charity and ceremonial strictness, the evidence from Costa Rica suggests the development and operation of three complementary governmental technologies.

\section{A Technology of Bio-Political Control}

The 'civilizing' of the natives and the policing of the Creoles and Spaniards by the Catholic regime in Costa Rica meant the development of both a power over individual sexual bodies and a power over populations (Foucault 1978).

\subsection{Power over Sexual Bodies}

The Catholic regime developed a particular emphasis on the government of the bodily movements of priests and lay individuals during religious rituals (Zavala-Pelayo 2016a, pp. 182-83). The evidence suggests that a pervasive governmental emphasis was also placed over the sexual dimension of bodies. Through catechisms, the natives were systematically taught the commandments "not to fornicate" and "not to covet your neighbor's wife"; to avoid these sins, "clean and pure living" (Torres and Betanzos 1905, pp. 38, 54) was demanded. These catechisms also included axiomatic statements about "lust" as one of the seven capital sins, and how "[t]he flesh" was "the biggest enemy" of the soul, because "we cannot get rid of it" (Torres and Betanzos 1905, pp. 53, 56). In his rather partisan essay, Ecuadorian historian Navarro (1955) argues that the Franciscans in the southern region of Talamanca taught the natives "about the animal and bodily life first", so that they could later influence the spiritual lives of the apprentices, for "it was pointless to try to teach them about the spiritual life without a bodily basis" (Navarro 1955, pp. 47-48). Similarly to the internalized symmetric charity above, these precepts and teachings were meant to be external and self-imposed rules (Klor 1991, pp. 16-17) of sexual behavior, enforced through two specific governmental techniques that did not necessarily depend on the priest-believer confession (Foucault 1978; Klor 1991) or the individual's self-production of truth ${ }^{11}$ (Foucault 2014), and can be observed at work in an

10 Or the primacy of Christianity's "external and institutional features" over "personal experience" that historian Barnadas (1984, p. 516) notices more generally in colonial Latin America.

11 The historically decisive self-reflexivity—or the inauguration of "Western subjectivity" (Foucault 2014, pp. 211, 266)—that Foucault observes in the European pastoralism and its practices of self-examination seems rather lacking in the archival and 
often-discussed institution, the Holy Inquisition. It is these techniques-inquisitional surveillance and community surveillance-rather than the above institution, that the paragraph below addresses.

Besides heresy, Lutheranism, and witchcraft, the inquisitional "gaze" (Foucault 2003) in the Americas policed the sexuality of the Natives and the Spanish and Creole settlers. The Inquisition in Guatemala-whose jurisdiction included the then province of Costa Rica-surveilled and punished "bad customs and irreligiosity", as both the "low clergy" and "the majority of the population" were prone to co-habitation without marriage, "illicit relationships", and "forgetting the rules of family relations" (Chinchilla 1953, pp. 197-200; cf. Klor 1991). Although cases of polygamy were just a few in the Guatemalan territory, and apparently there was only one in Costa Rica, there was a larger number of reports received by the Inquisitors in towns like Cartago (Chinchilla 1953, pp. 44, 179). The content of the reports from Cartago can be inferred from the Guatemalan Inquisition's general statistics. Whereas the reports on homosexual practices, incest, and rape were "sporadic" in the whole jurisdiction, the number of reports of bigamy, cohabitation without marriage, and "twice-married" individuals (Chinchilla 1953, pp. 217-18; see also Chuchiak 2012, pp. 6-7) appear comparatively higher-a total of 121 from the late 16th century to the end of the 18th century. Additionally, this inquisitional surveillance censored the "lascivious" books (Chinchilla 1953, pp. 299-311; see also Chuchiak 2012, p. 100) that circulated across the territory or were found in cargo vessels coming from Spain.

The policing of the sexual bodies of Costa Rica's inhabitants was also carried out through community surveillance. The Catholic regime, together with the bureaucratic apparatus of the Spanish Crown, seemed to have succeeded in converting lay individuals into non-official inquisitors who lacked punitive powers but represented effective enforcers of Christian sexual morality. The number of reports on the 'merits and services' of civil servants and local authorities who requested promotions or favors to the regal authorities, had to include testimonials of witnesses who confirmed both the good deeds and the proper marital status of the requester-and, as a consequence, the proper sexual behavior of the latter. The witnesses, for instance, corroborated that the petitioner was married "according to the command of the Holy mother Catholic Roman church" and that such a marriage was properly "public and notorious" (in Fernandez 1881, p. 163). Similarly, the explicit rules of Indigenous 'cofradias' demanded from their members the fulfillment of a monogamous "marital life" (Quiros 2013, p. 22). As a matter of fact, the processing of a case by the Holy Inquisition started often with a 'denuncia' by one of the accused's neighbors or acquaintances (Chinchilla 1953, pp. 96-100; Chuchiak 2012, pp. 1-2). As to the native population, this policing was assigned to the local cacique. In documents from a lawsuit processed in the early 1610s, cacique Juan Quetapa assures the authorities that he is a fair chief and punishes properly the "vices, witchcraft, and evils" (in Fernandez 1882, p. 181) of his subjects.

Resistances to this sexual control doubtlessly occurred. San Jose's archbishop (1940-1952), Victor Sanabria, notes in one of his books on the history of the Church in Costa Rica, the considerable number of "illegitimate children" (baptized children registered as born out of marriage) in the 17th century and the "licentious life", "debauchery", and wide-spread "lust" in "all types of families", in the late 18th century (Sanabria 1984, pp. 176, 262). In fact, the frequent cases of "concubinage" and "illegitimate" offspring, especially from the 1760s to the 1820s, made historian Acuña qualify both as the "primary mechanism" of racial mixing (Acuña 2011, p. 126). Fernandez (forthcoming) notes in passing that the colonial Church's sexually subjectifying discourses and practices contributed to the emergence of conditions of resistance, especially among the native population. At any rate, the occurrence of these resistances was coeval with the application of the two governmental techniques above.

documentary evidence of religious-governmental discourses and practices discussed in this paper. I have touched upon a similar intriguing finding elsewhere too (Zavala-Pelayo 2016a, p. 189). The matter certainly requires dedicated analyses that could not only explore further the finding but also analyze the possible consequences of this apparent gap in the types of (short-term? weak? selective?) societal reflexivity that can be observed in the socio-political dimensions of contemporary Latin American societies. 


\subsection{Power over Productive Populations}

Historiographical works by religious (e.g., Sanabria 1984; Picado 1985a) and some secular authors (e.g., Navarro 1955; Williams 1989) tend to portray the missionaries in Costa Rica as thoughtful humanitarian advocates who defended the native population against ruthless 'conquistadores' and greedy 'encomenderos'. As with elsewhere in the colonial Americas, the high clergy in Central America and the Franciscan missionaries in Costa Rica played the role of "protectors of Indians" (Sanabria 1984, pp. 55, 64); however, this protection was not exempt from a pragmatic concern for both teaching the native population "civilized" manual work skills, and putting new and old work skills to use ${ }^{12}$. Furthermore, the Catholic regime in Costa Rica, alongside the Spanish crown and other institutions such as the encomienda, contributed substantially to the colonial bio-power over the native populations by deploying external and internal(ized) techniques for the preservation and reproduction of the natives as an unpaid workforce. Regarding the latter type of techniques, catechisms represented again key discursive instruments. According to these religious textbooks, "laziness" was one of the seven capital sins and the Christian virtue that was meant to defeat it was indeed "diligence", together with the "suffering of exertion", which countered the fourth capital sin "anger" (Torres and Betanzos 1905, pp. 53-54). While the missionaries and parish priests instilled, or tried to instill, these ideas in the natives, the Catholic clergy and its missionaries managed ad hoc missions and towns of Indians, or 'reducciones de indios', for the "conservation" (Fernandez 1886, pp. 6, 10, 43, $145,253,326)$ of the latter. Such conservation, however, was utilitarian. As Franciscan missionaries in the early 18th century stated in a letter to the king, evangelization was important, but also, the fact that there were suitable "locations from which to extract these Indians for conversion and for work" (in Fernandez 1886, p. 433). The clerics' concern about the natives as labor force ${ }^{13}$ is confirmed by critical historians. Solorzano, for instance, points out that the friars' objective was to evangelize the native population and also make the latter "to carry out activities that benefited the missions" such as making crafts, caring for livestock, shepherding mules, and harvesting crops, in "heavy" and "extenuating" (Solorzano 2002, p. 58) working sessions. As a matter of fact, towns of Indians and missions were central not only for the regime's technology of bio-political control.

\section{A Technology of Geo-Political Rule}

Foucault (2007) distinguishes three regimes of spatial government that developed at different points in human history and have since then co-existed in European societies, the medieval and early post-medieval system of sovereign rule, the 18th century system of discipline, and the more "contemporary" apparatuses of security (Foucault 2007, p. 6) ${ }^{14}$. What Foucault missed was the role of pastoralism, or religious technologies of government, in the genealogy of modern geo-politics.

The geo-political expansionism of the Spanish Crown and explorers-traders in the colonization of the Americas cannot be understated (Elliot 2006). Such a geo-political drive, however, was not monopolized by the aforementioned agents. Pushed by the Protestant movements in Northern Europe, the Spanish Catholic Church embraced with zeal its commitment to both protect the Catholic faith and spread Christianity throughout the world. In his theological-political treaty on "the good government"

12 As one of the most renowned protectors, Bartolome de las Casas, noted in his Brevisima Relacion, the Natives were actually "the most delicate and fragile" people, but they were also "very capable and docile" and "very apt to [ ... ] be given virtuous habits" (De las Casas 1552, n.p.)

13 It is very likely that the Native population equated the modern concept of labor to their idea and practice of tribute (Melendez 1981; Sibaja 1983). At any rate, the Native population (Melendez 1981), and on occasions the civil authorities themselves (in Gonzalez 1902, pp. 26-27), tended to considered these tributes excessive.

14 For Foucault the regime of sovereignty dealt, with the proper "seat of government" (Foucault 2007, p. 20) and was therefore concerned with the ruling of a territory from a carefully assigned center. The disciplinary regime organized all the components of a whole in a hierarchical structure, as in the planning of 18th-century European towns based on a Roman-camp type of lay out. The apparatuses of security "fabricate, organize and plan a milieu", that is, the space "in which circulation", broadly conceived, "is carried out" (Foucault 2007, p. 21). 
of the Spanish colonies in the Americas, Spanish Franciscan friar Juan de Silva (1621) justifies the Church's evangelization campaign, citing one of the bible's psalms, "Et dominabitur a mari usque ad mare, et a flumine usque ad terminos orbis terrarium", which the friar interprets as a statement about "how this Holy Kingdom of the Redeemer shall be extended from sea to sea" and "to those [people] in America" (Silva 1621, p. 93). This discursive religious expansionism had a clear goal, additional to the massive religious conversions, namely, the (co-)creation and control of a properly Christian spatial-social order (see also Wilde 2009, p. 64; Sanchez 2016, pp. 62-63). The paragraphs below describe the hard and soft governmental techniques that were displayed to pursue this goal.

\subsection{Hard Techniques}

Hard techniques of the geo-political rule were applied for the 'occupation' and 'protection' of territories and spaces within colonial Costa Rica. The material instruments for territorial occupation included the so called 'reducciones' or towns of Indians, missions, and the central and transversal presence of the Catholic Church within the Costa Rican towns. As early as the 1520s and throughout the colonial period, the land that today comprises the territory of Costa Rica was appropriated by the Spanish conquistadores and their families (Quiros 2002, pp. 67-84). Although apparently lacking legal ownership (Picado 1985c, p. 197; Velazquez 2011), the Catholic clergy also contributed to the seizing of the land via the establishment of towns, or 'reducciones' for Indians, and missions. Religious historians note that the Franciscans established effectively the towns of Barba, Aserri, Curridabat, Ujarraz, Pacaca, and others, as early as the first half of the 1570s (Sanabria 1984, p. 105; Thiel 1902, p. 18). Although rather unsuccessful, the short-lived 'reducciones', founded intermittently by missionaries in the region of Talamanca from the 17th to the 18th century (Fernandez 1886, pp. 116-30, 149-51, 179), are illustrative of the clergy's procedures. They comprised the relocation of the indigenous population in different sites within the area originally populated by the natives; the relocation of the natives in areas far from the original indigenous settlements, to avoid retaliation by the unconverted natives; and the simultaneous establishment of towns of Spaniards and towns of Indians, as the former were meant to be stable anchors (Fernandez 1886, p. 241; Sanabria 1984, pp. 158-59), and exploitative workplaces (Quiros 2002; Solorzano 2002) for the inhabitants of the latter.

The central and transversal presence of the Catholic Church within towns represented another material instrument of territorial occupation. As elsewhere in other regions (Sanchez 2016, pp. 62-63), the position of the main parish next to the local council in the central square of the Costa Rican towns afforded the Catholic regime a symbolic authority status. As the blueprint of the town of Cartago in 1608 suggests (Fallas 2017; see also León and López 1996, p. 178), this symbolic status was reinforced in some towns by the religious buildings located on opposite sides of the town's outskirts, making the presence and symbolic authority of the church not only central, but transversal too. It is this transversality principle that led the bishop in charge of the Costa Rican province in 1711 to order the construction of worshipping places for the scattered population living in the peripheries of Nicoya, Esparza, and Cartago (Sanabria 1984, p. 184). Towns for the indigenous populations were not an exception in this regard. Franciscan friars sometimes relocated different ethnic groups within their missions and tried to assign both a specific place as well as a "particular saint" and "hermit" to each group (Solorzano 2002, p. 65).

The protection of the territory by the Catholic Church was carried out via frontier missions and intra-frontier settlements. Frontier missions in the north of New Spain (south of the United States today) have been described by a religious author as "frontier institutions to whom fell the task of extending and holding the frontiers" (Bolton 1917, p. 43). At times unsuccessfully, Costa Rica counted on frontier missions as well. In the first half of the 18th century, the governor of Costa Rica criticized the "deplorable and pitiful state" of the Franciscan missions in Talamanca, and the resulting "capture of natives by the Mosquito Indians who sell them [natives] to the English men in Jamaica" (in Gonzalez 1902, pp. 21-22). Inner borders were a governmental priority as well. Picado notes 
that the 'reducciones' ran by Franciscans were strategically situated around the Spanish towns in the central valley and "prevented attacks from non-Christian Indians" (Picado 1985b, p. 142).

\subsection{Soft Techniques}

The (co-)creation and control of the Christian spatial-social order included soft means as well. Religious agents in the province of Costa Rica were knowledgeable not only of spiritual and theological matters, but also of their geographical surroundings. Lengthy descriptions of the local geography, flora, fauna, and natural resources were systematically produced by both members of the high and low clergy. Franciscan friar Agustin de Ceballos, in the early 17th century, for instance, wrote a letter to the king that included a thorough report on the province's land area, its borders, local native groups, the weather, the region's animals and vegetation, and information on hydrographic and mineral resources (in Peralta 1883, pp. 697-704). The bishop in charge of the province of Costa Rica in the mid-18th century submitted to the king a letter titled "Apostolic, Topographic, Historic, and Statistical Visit of all the towns of Nicaragua and Costa Rica" (cited in Sanabria 1984, p. 255; see also Klor 1991, pp. 10-11).

The soft techniques of geo-political rule by the Catholic regime also included a systematic counselling. In his "Treaty on the Republic", discalced Spanish Franciscan friar Juan de Santa Maria states that "if a Prince wants to be very zealous about the good of his Republic" and "would want to be assisted, he has true and assured remedies for that, all of them dictated by the holy Spirit" (De Santa-Maria 1618, pp. 26-27). The Catholic Church and its agents often turned to solicited counselling, or blunt unsolicited lobbying, for fulfilling their geo-political governmental drive-and the geographical knowledge they systematically gathered or produced came in handy for this. Religious agents in Costa Rica, not unfrequently, advised the king and other authorities about auspicious locations for building towns, roads, and even ports and docks. In a letter written by Franciscans based at Cartago, and addressed to the Spanish king at the end of the 16th century, the authors declare that they "know the land and have threshed it", and therefore suggest to the king the establishment of a "town of Spaniards" and a port in "the Northern Sea" nearby the Suerre river ${ }^{15}$, so that "sea business" could be carried out and the royal treasury and the province of Costa Rica could "grow prosper" (in Peralta 1883, p. 607). The detailed report by friar Ceballos above, is, in fact, the technical annex of a letter that informs the king about the "infinity of souls" that could be better "administered" in the region and the "inestimable wealth that His Majesty is missing and the ease to possess it" (in Peralta 1883, p. 697). The Catholic regime itself was also interested in matters related to material wealth and, more importantly, their efficient administration.

\section{A Technology of Administrative Efficiency}

Foucault's monastic and inward-looking pastoralism did not only miss the geopolitical component of religious (proto-)governmentality beyond Europe, it also overlooked the latter's governmental methodology of administrative efficiency ${ }^{16}$. The colonial Catholic regime in Costa Rica seems driven not by what scholar Curtis (2017, p. 155) calls a "moral political economy" of the pastorate, but by a more pragmatic concern for the efficient administration of subjects and objects. The Franciscans in particular seemed concerned about efficiency-related matters, even before the colonization of the Americas. As can be inferred from Francis of Assisi's Regula Bullata, this order was instructed upon a (proto-)logic of minimization of inputs (e.g., poverty) and quantitative or qualitative maximization of outputs (e.g., virtues). Hence, the Regula Bullata's chapter VI notes "that loftiness of most high poverty, has established you, [ ... ] as heirs and kings of the Kingdom of Heaven, making you

15 Today Limon's province, eastern Costa Rica.

16 Doubtless the regime's technology of administrative efficiency can be analyzed in tandem with the Weberian classic thesis on the Calvinist spirit of capitalism. Although these combined approach would be possible only if the Weberian institutional-modern approach and the Foucauldian post-modern meta-institutional strategy are reconciled, the resulting analysis could shed light on an "extra-religious" element of Christian religions that is seldom discussed (cf. Mutch 2017). 
poor in things, it has raised you high in virtues" (Assissi 1982, n.p.). A clearer instance of this input-minimization-output-maximization (proto-)logic can be found in chapter IX:

I also warn and exhort $[\ldots]$ friars [ $\ldots$ ] their expressions be examined [ ... ], for sake of the utility and edification of the people by announcing to them vices and virtues [ ... ] with brevity of speech; since a brief word did the Lord speak upon the earth. (Assissi 1982, n.p.; emphasis added)

The American colonies proved to be the perfect sites for the application of this governmental rationale. It is not coincidental that Franciscan Juan de Silva stated boldly, in his treaty on the "administration" of Spain's colonies, that "the conversion and spiritual good" of the Indians can be achieved by "setting and correcting the most convenient, most suitable and efficacious means" (Silva 1621, p. 7; emphasis added). The application of this efficiency logic can be observed through two specific techniques, systematic accounting, and optimization of evangelization and economic "minutiae" (Foucault 1977b, pp. 139-40).

\subsection{Systematic Accounting}

Foucault's pastoral principle of "analytical responsibility" (Foucault 2007, pp. 169-70) might have well materialized in a specific type of governmental instrument in colonial Costa Rica. The Spanish Catholic regime's obsessive emphasis over the quantity of converted souls made priests and missionaries particularly concerned about registering the numbers of baptisms, as well as marriages and deaths. The numbers in these ecclesiastical registries might have been overestimated (Quiros 2002, p. 211), but regardless of precision, these records represented a high-priority assignment and, more importantly, contained key information for the government of the population. Besides functioning as a basic census (in Fernandez 1886, pp. 353, 375-77; Thiel 1902), the baptism registries pointed the juridical status (Quiros 2002, p. 212) of the baptized, according to the status (e.g., Indians in encomienda or Indians in service) of his/her parents. The above records did not necessarily represent "a mechanism of exploitation" (Quiros 2002, p. 119) per se, but they were doubtless an instance of the accounting technique that was conducive to the enforcement of the technology of administrative efficiency, as well as that of bio-political control introduced above. These systematic accounting practices developed over time into more complex socio-demographic records. For instance, a missionary in the south of Costa Rica produced by the end of the 17th century a "statement of the houses and goods of the Terrabas" and specified that the Durucas and Texabas people,

exchange cotton blankets that are used as [bed] covers and curtains; and the Bunicas give them salt, axes, machetes, dogs and other things. And they bring salt and hamocs, to the Changuenes and they bring from them coral necklaces, colored feathers, and some beads [ ... ]. (Fernandez 1886, p. 370)

In fact, the geographical knowledge produced as part of the regime's technology of geo-political rule, were also accompanied by detailed technical reports that included the names of towns, the nearest rivers per town, the number of houses and caciques in each town, and the number of days or hours it took to go from one site to the other (in Fernandez 1886, pp. 369-77).

\subsection{Optimization of Evangelization and Economic Matters}

As the material and human resources for a universal evangelization (Silva 1621) were not likewise universal, the Catholic Church and its members prioritized the optimization of their tasks and resources. During the early period of colonization, Franciscan friar Lorenzo de Bienvenida complained to the king, not about the fact that Indians were being seized and exploited by the Spanish conquistadores through 'encomiendas', but about the inefficient and disordered distribution of the natives among the 'encomenderos' (in Peralta 1883, pp. 550-52). Bienvenida notes sternly that governor Perafan de Rivera and his successor Anguciana gave the land, "and even the mounts, the rivers, the hills, and the stones" to "Creoles, blacks, and other low people", instead of giving them to "distinguished" (Peralta 1883, p. 551) Spaniards, who would have better collaborated in the conversion of the natives. 
Such a concern for effectiveness was also observed in the clergy's emphasis on the optimization of economic matters. Considerable attention by the clergy was paid, for instance, to the towns' wealth and the local economies-partly because of the fact that the formers' salaries were often obtained from the tribute extracted from the native population. Hence, a priest in central Costa Rica by the end of the 18th century notes optimistically how the region has "a healthy atmosphere, a very fertile soil, and holds the best [ ... ] wood for the construction of houses" (in Gonzalez 1902, p. 9). Less enthusiastic, the newly appointed bishop of Nicaragua complains in a letter to the king in the mid-16th century, about the fact that the 1500 'maravedies' his salary amounted to equated only to 300 in his new jurisdiction, because "what here costs two pesos there [new jurisdiction] costs eight or nine" (in Peralta 1883, p. 154).

The practices of economic optimization can also be observed at play in cases of the "efficient" monetary and non-monetary fees the indigenous population had to pay upon the clergy's demand. In the second half of the 18th century, a group of native individuals wrote a letter to the king asking for his intervention, because the local priest reportedly charged them "rations for their sustenance" and made them pay "tithes, tributes, [fees for] marriages, everything in silver [currency]" (in Gonzalez 1902, pp. 54-55). Similarly, Costa Rica's governor Carrandi y Menan in 1737 reports how priests in Cartago charged every Indian who attended mass "one ounce of purple yarn that costs four reales" (in Gonzalez 1902, pp. 26-27) ${ }^{17}$.

The above set of efficiency-concerned practices also comprised systematic advices to secular authorities on the same type of matters, either because the religious advisor was interested in the potential benefits for evangelization or because he was moved by material interests. For instance, the bishop of Nicaragua and Costa Rica advised the Spanish king in the 1540s on the building of a dock and channels in strategic points along the Atlantic coast in such a way that, not only the "many deaths", but also the "costs" that the old transport routes caused would decrease (in Gonzalez 1902, pp. 142-56). Having a similar priority in mind, Friar Antonio de Margil notes in a letter to the king in the early 18th century, that "other than the conversion of souls" in Costa Rica, it was also possible in that region "to expand the [Crown's] realm and so increase considerably the [number of] vassals and tributes, and the utility that the minerals [of the region] [ ... ] promise" (in Fernandez 1886, p. 416). Such an optimization-oriented advisory technique was in fact similar to the technique of counselling systematically deployed by the Catholic regime's technology of geo-political rule. This composite and simultaneous operation of governmental techniques, and the emergent and complex composition of the technologies, discussed above, leads to the next topic.

\section{An Ensemble of Changing Technologies}

In addition to the deployment of the technologies of charity and ceremonial strictness in Costa Rica, the sections above describe both the logics (patterns of discourses) and the techniques (patterns of practices) of three religious governmental 'techno-logies' that cannot be inferred, at least not directly, from Foucault's original theorizations on Christian pastoralism-bio-political control, geo-political rule, and administrative efficiency. These elements of the Catholic governmental regime in Costa Rica did not operate as discreet, independent parts. The evidence suggests that the technologies and their particular logics and techniques, were applied simultaneously, fed each other, and transformed over time; what emerged (Foucault 1977a) out of this was a complex ensemble of religious technologies of government. This section discusses exploratory findings in this regard.

As the bishop of Nicaragua and Costa Rica's advice on the strategic construction of docks and channels over the Atlantic coast point above, the technology of administrative efficiency was often accompanied by the deployment of geographical knowledge and the practice of counselling. In other words, the technology of administrative efficiency drew on the same soft techniques used by the

17 Further details on this, so to speak, exploitative optimization can be found in the critical works by Quiros (2002) and Solorzano (2002), as well as Sanabria's insider accounts (Sanabria 1984, pp. 100-1, 246-50, 272; cf. Picado 1985c, p. 197). 
technology of geopolitical rule. In addition to the shared use of techniques, it is also possible to observe a simultaneous application of such technologies. This is evident, for instance, in the use of the technology of charity together with the technology of geo-political rule. Although the Spanish military often forced the relocation of the natives into 'reducciones' (in Fernandez 1886, pp. 147-51), the seizing of the natives was sometimes carried out through the technology of charity or "pious means" (Fernandez 1886, p. 241; see also Sanabria 1984, p. 208) deployed by the missionaries. Besides working side by side, the religious governmental technologies above reinforced each other.

Just like Quiros and her reference to baptismal registries as "mechanisms" of labor exploitation, Jáuregui and Solodkow (2014) touch upon "the census and the questionnaires" by religious agents in colonial Santo Domingo (Dominican Republic), and refer to them as 'biopolitical' "disciplinary dispositives" (2014, p. 154). In the case of Costa Rica, both conceptualizations may stretch too far; the clergy's records and censuses represented material instances of a specific technique that was used by different religious technologies, which jointly led to discipline and exploitation. However, the authors above address, indeed, what the evidence points out. The systematic-accounting technique of the technology of administrative efficiency, and the technique's material instruments (in particular, its socio-demographic records) assisted the operation of the hard techniques of geopolitical rule, that is, the occupation and protection of territories through 'reducciones', missions, and the central and transversal presence of the Church within towns. Those socio-demographic records, with their detailed classification of subjects and objects, also supported the technology of bio-political control and its power over sexual bodies and productive populations. The technologies of geo-political rule and bio-political control were in turn substantially intertwined. The technology of geo-political rule deployed through 'reducciones' and the central/transversal co-structuring of towns, made doubtless the physical distance between the natives and the religious agents' "gaze" (Foucault 2003) shorter and, as a result, facilitated the inquisitional and community surveillance of the population as well as the management of the population's labor force (Quiros 2002; Solorzano 2002). These external means of bio-political control enabled, on the one hand, the sexual self-control expected by the religious agents from indigenous, creoles, and Spaniards alike, and, on the other hand, the population's "passive" (Foucault 2007, p. 194) or organized resistance in this and other governmental fields ${ }^{18}$ (e.g., Quiros 2013, pp. 8-9).

However, the evidence suggests that the technologies and techniques above were not combined evenly, or were not impervious to change. It is safe to argue that, in order to ease the evangelization, the techniques of self-government above-i.e., internal(ized) symmetric charity; bodily self-control—together with the external control of the natives' sexual bodies and some of the hard and soft geopolitical techniques were deployed more heavily during the initial stages of colonization. Refined versions of administrative efficiency might have been deployed more frequently at later stages. Indeed, the objectives of the Enlightenment-inspired Bourbonic reforms implemented in the second half of the 18th century in Spain and its American colonies included a stronger centralization of the state's administration and gain-seeking restructuration of economic activities (Elliot 2006). Although these reforms were implemented rather late in Costa Rica, they likely brought changes to the religious governmental techniques above, for instance, an emphasis on "scientific" discourse in accounting registries and records of geographical knowledge. Bishop Morel's report "Apostolic, Topographic, Historic, and Statistical Visit of all the towns of Nicaragua and Costa Rica" (Sanabria 1984, p. 255) may well be a case in point. All in all, the differential combinations, external resistance, internal tensions,

18 Regardless of whether the Holy Inquisition's censorship was successful or not, it is minimal the empirical evidence in the data set that suggests these specific resistances operated together with an explicit counter-theology or alternative governmental doctrine (cf. Quiros 2013). For this reason, the term resistance is preferred over the Foucauldian "counter-conduct" (Foucault 2007). However, a dedicated genealogy of overt and covert resistances and counter-conducts in the colonial religious field, in Costa Rica and elsewhere, is a promising subject for further genealogical research. 
and diachronic changes at the level of the techniques and the governmental technologies above, constitute themes worth studying in further investigations.

\section{Conclusions}

Had Foucault studied the governmental discourses and practices implemented by the Catholic regime in colonial Latin American regions, such as Costa Rica's, his theorizations on pastoralism and governmentality (Foucault 2007, 2011, 1983) would have likely developed in a different fashion. Foucault's genealogical notes addressed the birth of both the government of space and territories, and the government of economic matters (Foucault 2007). Regarding the former, his references to a sovereign power that rules over a territory from a carefully designated center (Foucault 2007, p. 20), the disciplinary system that organizes a town in a hierarchical order, and the apparatuses of security that "fabricate" a "milieu" (Foucault 2007, p. 21), are described as overlapping epochal modes of control/government, with no direct and substantial links to religious technologies of government. Foucault's pastoral government "is not exercised over a territory" (Foucault 2007, p. 125) either. Regarding economic matters, the pastoral "economy of souls" that Foucault ponders (Foucault 2007, p. 192) is devoid of references to the type of material, economic, and pragmatic religious matters discussed in the previous sections. For Foucault, external "economic problems" were only "translated into" (Foucault 2007, p. 215) religious themes in the Middle Ages; the government of the former was not religious per se, and did not constitute any pastoralism. For Foucault, a properly pragmatic and calculative political economy that conceives the government of living populations emerged until the 18th century. However, the evidence above suggests that the religious technologies of government in colonial Costa Rica operated, simultaneously, as a quasi-sovereign power that ruled over a territory, and an apparatus of security that, just like Foucault's 18th century political economy, policed the "volume", "density", and movements of populations using "economic knowledge" (Foucault 2007, p. 110), as early as the 1560s. Additionally, the Catholic regime in colonial Costa Rica did not necessarily develop a governmental technique of power over bodies first, and a more technical power for the government of entire populations thereafter (Foucault 1978); it developed both types of bio-powers at the same time, alongside a systematic, efficiency-driven registry and surveillance of economic, geo-political, and "life processes" (Foucault 1978, p. 142). The short- and long-term consequences of this, in a sense proto-liberal (Foucault 2007, p. 48), simultaneity of religious technologies are topics worth studying further.

The classic and contemporary literature on the colonial and religious institutions that were partly discussed above- 'cofradías', the Inquisition, the 'encomienda', and the mission-is doubtless large. By addressing these institutions, critical historians have contributed with valuable works on the mechanisms of (exploitative) societal control implemented by the Catholic Church in colonial Latin America. Some of those mechanisms have been discussed, indeed, through the disciplinarian lens (e.g., Klor 1991) or the framework of (bio-political) governmentality (e.g., Jáuregui and Solodkow 2014) proposed by Foucault. What this article puts forth, however, is not a single clear-cut control mechanism or governmentality tactic, but a heterogeneous, complex, and changing ensemble of distinctive-i.e., bio-political, geo-political, charity-, ceremoniality-, and efficiency-related-governmental technologies displayed by the colonial Catholic regime in Costa Rica, as well as the specific logics and techniques that constituted these technologies. The resulting analysis and conceptualizations are offered as contributions that complement the Foucauldian and the institutionalist literature published to date.

The conceptualizations in this article are also offered as contributions to the institution-centered literature that addresses the operational fields above in contemporary societies, in Latin America or elsewhere. For instance, whereas the institutional geo-politics of the Catholic Church in past and present global politics has been discussed (Agnew 2010; Kratochvíl and Doležal 2015), the findings above point out a complex religious governmental regime, whose operation involved the deployment of a meta-institutional technology of geo-political rule, with its particular logics, as well as soft and hard techniques, which cannot be reduced to the clergy's deliberate policies. The technology of bio-political control, above, and its accompanying logics and techniques, may also provide the growing literature 
on the disciplining of (sexual) bodies (e.g., Segato 2014) and the juridical and political struggles over sexual and reproductive rights in Costa Rica (e.g., Arguedas Ramírez 2010), Latin America (e.g., Corrales and Pecheny 2010), and other world regions, with a non-normative conceptual framework that problematizes reductionist and synchronicistic views of religious institutions and discourses. The governmental technology of administrative efficiency can be considered a departure point for empirical studies on the development of economic theologies (Agamben 2011) and the (religious) genealogy of contemporary economic thought (Nelson 2006) in and beyond the West/s. This paper's conceptual contributions overall endorse the relevance of analyzing religions and politics in past and contemporary societies, through the lens of centuries-lasting and changing religious technologies of government.

Funding: This research received no external funding.

Acknowledgments: Earlier versions of this paper were presented at one of the research seminars of Stockholm University's Institute of Latin American Studies and a workshop on 'Religion and Society in Latin America' held at the University of Bern. I thank the attendants to both events for their helpful comments. I shall also thank Bjørn O. Tafjord for his comments and suggestions, and the journal's reviewers for their critical feedback.

Conflicts of Interest: The author declares no conflict of interest.

\section{References}

Acuña, María de los Ángeles. 2011. Mestizaje, concubinato e ilegitimidad en la provincia de Costa Rica, 1690-1821. Cuadernos Intercambio 8: 125-44.

Agamben, Giorgio. 2011. The Kingdom and the Glory. For a Theological Genealogy of Economy and Government. Stanford: Stanford University Press.

Agnew, John. 2010. Deus Vult: The Geopolitics of the Catholic Church. Geopolitics 15: 39-61. [CrossRef]

Aragon, Jorge. 2014. Religión, religiosidad y orientaciones políticas en el Perú. Religioni e Società 29: 77-88. [CrossRef]

Araya, Jorge. 2017. Conservadurismo y Actitudes Autoritarias Prevalecen Entre Costarricenses. Semanario Universidad, January 18. Available online: https://semanariouniversidad.com/pais/conservadurismo-actitudes-autoritariasprevalecen-costarricenses (accessed on 20 January 2017).

Arguedas Ramírez, Gabriela. 2010. El (aún) tortuoso camino hacia la emancipación: Fundamentalismos religiosos, los derechos humanos de grupos históricamente oprimidos y la lucha por un Estado Laico en Costa Rica. Anuario Centro de Investigación y Estudios Políticos 1: 50-65.

Assissi, Francis of. 1982. The Regula Bullata of St. Francis of Assisi. Translated from the Latin Text, published in Li Scritti di S. Francesco D'Assisi: Nova Edizione Critica e Versione Italiana. First published 1226. Available online: https:/ / franciscan-archive.org/bullarium/TheRegulaBullataLSz.pdf (accessed on 14 March 2017).

Barnadas, Josep. 1984. The Catholic church in colonial Spanish America. In The Cambrdige History in Latin America, Volume I. Colonial Latin America. Edited by Leslie Bethell. Cambirdge: Cambirdge University Press, pp. 511-40.

Behrent, Michael C. 2012. "The genealogy of genealogy: Foucault's 1970-1971 course on The will to know", review of Leçons sur la volonté de savoir. Cours au Collège de France (1970-1971) by Michel Foucault. Foucault Studies 13: 157-78. [CrossRef]

Bejerot, Eva, and Hans Hasselbladh. 2011. Professional Autonomy and Pastoral Power: The Transformation of Quality Registers in Swedish Health Care. Public Administration 89: 1604-21. [CrossRef]

Bolton, Herbert. 1917. The Mission as a Frontier Institution in the Spanish-American Colonies. The American Historical Review 23: 42-61. [CrossRef]

Booth, John, Wade Christine, and Walker Thomas. 2010. Understanding Central America. Boulder: Westview Press.

Bröckling, Ulrich, Susanne Krasmann, and Thomas Lemke. 2011. From Foucault's Lectures at the College de France to Studies of Governmentality: An Introduction. In Governmentality. Current Issues and Future Challenges. Edited by Bröckling Ulrich, Susanne Krasmann and Thomas Lemke. London: Routledge, pp. 1-33.

Carrette, Jeremy. 2000. Foucault and Religion. Spiritual Corporality and Political Spirituality. London: Routledge. 
Chinchilla, Ernesto. 1953. La Inquisición en Guatemala. Guatemala: Editorial del Ministerio de Educacion Publica.

Chrulew, Matthew. 2013. Suspicion and Love. Foucault Studies 15: 9-26. [CrossRef]

Chrulew, Matthew. 2014. Pastoral counter-conducts: Religious resistance in Foucault's genealogy of Christianity. Critical Research on Religion 2: 55-65. [CrossRef]

Chuchiak, John F. 2012. The Inquisition in New Spain, 1536-1820: A Documentary History. Baltimore: Johns Hopkins University Press.

Cordoba, Julio. 2014. Viejas y nuevas derechas religiosas en América Latina: Los evangélicos como factor político. Nueva Sociedad 254: 112-23.

Corrales, Javier, and Mario Pecheny. 2010. The Politics of Sexuality in Latin America. Pittsburgh: University of Pittsburgh Press.

Curtis, Bruce. 2017. Pastoral power, sovereignty and class: Church, tithe and simony in Quebec. Critical Research on Religion 5: 151-69. [CrossRef]

De las Casas, Bartolome. 1552. Breussima relacion de la destruycion de las Yndias. N.p.

De Santa-Maria, Johannes. 1618. Tratado de Republica y Policia Christiana. Barcelona: Sebastian de Cormellas.

Dean, Mitchell. 2010. Governmentality: Power and Rule in Modern Society. London: Sage.

Elliot, John H. 2006. Empires of the Atlantic world: Britain and Spain in America, 1492-1830. New Haven and London: Yale University Press.

Fallas, Carlos. 2017. Proyecto Inventario Arquitectónico Ciudad de Cartago, Provincia de Cartago. Reseña Histórica del Casco Antiguo de la Ciudad de Cartago. Ministerio de Cultura, Juventud y Deportes. Available online: http:/ / www.patrimonio.go.cr/biblioteca_digital/inventario/2003_ia_de_cartago.aspx (accessed on 10 August 2017).

Fernandez, D. Leon. 1881. Colección de documentos para la historia de Costa Rica, Tomo I. San Jose de Costa Rica: Imprenta Nacional.

Fernandez, D. Leon. 1882. Colección de documentos para la historia de Costa Rica, Tomo II. San Jose de Costa Rica: Imprenta Nacional.

Fernandez, D. Leon. 1886. Colección de documentos para la historia de Costa Rica, Tomo V. San Jose de Costa Rica: Imprenta Nacional.

Fernandez, Ana Lucia. Forthcoming. Discurso, Poder y Sometimiento en los Cuerpos Racionalizados, Sexualizados y Feminizados en America Latina durante la Conquista. In Racismo, cuerpo y violencia en América Latina. Edited by Lizette Jacinto and Jorge Puebla Gómez. Puebla: Benemérita Universidad Autónoma de Puebla.

Fonseca, Elizabteh. 1983. Costa Rica Colonial. La tierra y el Hombre. Costa Rica: Editorial Universitaria Centroamericana. Foucault, Michel. 1977a. Nietzsche, Genealogy, History. In Language, Counter-Memory, Practice: Selected Essays and Interviews. Edited by Donald F. Bouchard. Ithaca: Cornell University Press, pp. 139-64.

Foucault, Michel. 1977b. Discipline and Punish. The Birth of the Prison. New York: Vintage.

Foucault, Michel. 1978. The History of Sexuality. Volume I: An Introduction. New York: Pantheon Books.

Foucault, Michel. 1983. The Subject and Power. In Foucault: Beyond Structuralism and Hermeneutics. Edited by Hubert L. Dreyfus and Paul Rabinow. Chicago: The University of Chicago Press, pp. 208-26.

Foucault, Michel. 1993. About the Beginning of the Hermeneutics of the Self: Two Lectures at Darthmouth. Political Theory 21: 198-227. [CrossRef]

Foucault, Michel. 2003. The Birth of the Clinic. London: Routledge Classics.

Foucault, Michel. 2007. Security, Territory, Population: Lectures at the College de France 1977-78. Basingstoke: Palgrave Macmillan.

Foucault, Michel. 2008. The Birth of Bio-Politics. New York: Palgrave Macmillan.

Foucault, Michel. 2011. Omnes et Singulatim: Towards a Criticism of 'Political Reason'. In The Tanner Lectures on Human Values. Edited by Sterling McMurrin. Salt Lake City: University of Utah, vol. 2, pp. 224-5.

Foucault, Michel. 2014. On the Government of the Living. Basingstoke: Palgrave.

Freston, Paul. 2013. The Future of Pentecostalism in Brazil: The Limits to Growth. In Global Pentecostalism in the Twenty-First Century. Edited by Robert Hefner and Peter Berger. Indiana: Indiana University Press, pp. 63-90.

Garland, David. 2014. What is a "history of the present"? On Foucault's genealogies and their critical preconditions. Punishment \& Society 16: 365-84. [CrossRef] 
Golder, Ben. 2007. Foucault and the Genealogy of Pastoral Power, Review of Security, Territory, Population: Lectures at the Collège de France, 1977-1978 by Michel Foucault. Radical Philosophy Review 10: 157-76. [CrossRef]

Gonzalez, Cleto. 1902. Documentos para la Historia de Costa Rica. San Jose: Tipografia Nacional.

Gutierrez-Haces, Maria Teresa. 1987. Costa Rica: La desmitificación de una democracia. In Centroamerica: Una Historia sin Retoque. Edited by Cueva Agustín. Mexico: Sociedad Cooperativa Publicaciones Mexicanas, Instituto de Investigaciones Economicas, UNAM, pp. 15-66.

Hearn, Jonathan. 2008. What's wrong with domination? Journal of Power 1: 37-49. [CrossRef]

Hernández, Oriester Abarca, and Jorge Bartels Villanueva. 2011. El papel economico de las cofradias en el crepusculo de la Colonia y el ascenso de las sociedades mercantiles. Ciencias Economicas 29: 357-83.

Hidalgo, Antonio J. 2013. De Cofradías y Hermandades en Guatemala (1993-2012). Diálogos Revista Electrónica de Historia 14: 29-76. [CrossRef]

Jáuregui, Carlos A., and David M. Solodkow. 2014. Biopolitica colonial, gestion de la población y modernización borbónica en Santo Domingo. El proyecto de Pedro Catani (1788). Perifrasis 5: 140-68. [CrossRef]

Jerez-Brenes, Verónica. 2016. Las ordenanzas de una cofradía de sangre: La cofradía de San Nicolás de Tolentino, 1641. Revista Espiga 15: 63-80. [CrossRef]

Jones, Daniel, and Santiago Cunial. 2017. Más allá de los límites del Estado. Instituciones católicas y evangélicas de partidos del Gran Buenos Aires (Argentina) en la implementación de políticas públicas sobre drogas. Desafíos 29: 85-123. [CrossRef]

Klor, Jorge. 1991. Colonizing Souls: The Failure of the Indian Inquisition and the Rise of Penitential Discipline. In Cultural Encounters: The Impact of the Inquisition in Spain and the New World. Edited by Perry Mary Elizabeth and Anne J. Cruz. Berkeley: University of California Press, pp. 3-23.

Kratochvíl, Petr, and Tomáš Doležal. 2015. The European Union and the Catholic Church Political Theology of European Integration. London: Palgrave Macmillan.

León, María de los Angeles Acuña, and Doriam Chavarria López. 1996. Cartago colonial: Mestizaje y Patrones Matrimoniales, 1738-1821. Mesoamerica 31: 157-79.

Maroto, Adriana. 2014. Intercambio de obsequios y contraobsequios: Construcción de la legitimidad en las relaciones estado-iglesia católica en Costa Rica, 2007-2010. Anuario de Estudios Centroamericanos 40: 289-310.

Mason, Jennifer. 2002. Qualitative Researching. London: Sage.

Mayes, Christopher. 2009. Pastoral power and the confessing subject in patient-centred communication. Journal of Bioethical Inquiry 6: 483-93. [CrossRef]

Melendez, Carlos. 1981. Acerca del trabajo indígena en Costa Rica durante el siglo XVII. Cahiers du Monde Hispanique et Luso-Brésilien 37: 37-50. [CrossRef]

Mora, Arnoldo. 1992. Historia del Pensamiento Costarricense. San José: Editorial Universidad Estatal a Distancia.

Mutch, Alistair. 2017. "Decently and order": Scotland and Protestant pastoral power. Critical Research on Religion 5: 79-93. [CrossRef]

Navarro, Jose G. 1955. Los franciscanos en la conquista y colonización de América. Madrid: Ediciones Cultura Hispanica.

Nelson, Robert H. 2006. Economics as Religion. From Samuelson to Chicago and Beyond. State College: The Pennsylvania State University.

Pansters, Krijn. 2012. Franciscan Virtue: Spiritual Growth and the Virtues in Franciscan Literature and Instruction of the Thirteenth Century. Leiden: Brill.

Peralta, Manuel M. 1883. Costa Rica, Nicaragua y Panama en el siglo XVI. Su Historia y sus Límites según los Documentos del Archivo de Indias de Sevilla, del de Simancas, etc.. Madrid: Librería de M. Murillo, Paris: Librería de J.I. Ferrer.

Petterson, Christina. 2014. The Missionary, the Catechist and the Hunter: Foucault, Protestantism and Colonialism. Brill: Leiden.

Picado, Miguel. 1985a. Costa Rica [Primer Periodo. La evangelización]. In Historia General de la Iglesia en America Latina, VI, America Central. Edited by Enrique Dussel, Rodolfo Cardenal, Ricardo Bendaña, Jorge Eduardo Arellano, Marcos Carias, Miguel Picado and Wilton Nelson. Salamanca: Ediciones Sigueme, pp. 70-76.

Picado, Miguel. 1985b. Costa Rica [Segundo Periodo. La organización de la Iglesia en Centro America]. In Historia General de la Iglesia en America Latina, VI, America Central. Edited by Enrique Dussel, Rodolfo Cardenal, Ricardo Bendaña, Jorge Eduardo Arellano, Marcos Carias, Miguel Picado and Wilton Nelson. Salamanca: Ediciones Sigueme, pp. 134-43. 
Picado, Miguel. 1985c. Costa Rica [Tercer periodo. La vida cotidiana de la cristiandad cetroamericana]. In Historia General de la Iglesia en America Latina, VI, America Central. Edited by Enrique Dussel, Rodolfo Cardenal, Ricardo Bendaña, Jorge Eduardo Arellano, Marcos Carias, Miguel Picado and Wilton Nelson. Salamanca: Ediciones Sigueme, pp. 197-98.

Pinto, Julio Cesar. 1993. Historia General de Centroamerica. Tomo II. El régimen colonial (1524-1750). Madrid: Facultad Latinoamericana de Ciencias Sociales.

Quiros, Claudia. 2002. La Era de la Encomienda. San Jose: Editorial de la Universidad de Costa Rica.

Quiros, Claudia. 2013. Cofradias indígenas de Nicoya. Unpublished Paper. Available online: http:/ / repositorios. cihac.fcs.ucr.ac.cr/cmelendez/handle/123456789/1832 (accessed on 31 May 2018).

N.a. 1996. Constitucion Politica de la Republica de Costa Rica. San Jose: Asamblea Legislativa, Centro para la Democracia.

Rodríguez, Eugenia. 2014. Controlando y regulando el cuerpo, la sexualidad y la maternidad de las mujeres centroamericanas (siglo XIX e inicios del siglo XX). Cuadernos Intercambio sobre Centroamérica y el Caribe 11: 233-58. [CrossRef]

Saar, Martin. 2011. Relocating the Modern State: Governmentality and the History of Political Ideas. In Governmentality. Current Issues and Future Challenges. Edited by Ulrich Bröckling, Susanne Krasmann and Thomas Lemke. London: Routledge, pp. 34-55.

Sanabria, Victor. 1984. Reseña histórica de la Iglesia en Costa Rica desde 1502 hasta 1850. San Jose: Departamento Ecumenico de Investigaciones.

Sanchez, Rafael. 2016. Dancing Jacobins. A Venezuelan Genealogy of Latin American Populism. New York: Fordham University Press.

Segato, Rita. 2014. Las Nuevas Formas de la Guerra y el Cuerpo de la Mujeres. Puebla: Pez en el árbol.

Sibaja, Luis F. 1983. La encomienda de tributo en el Valle Central de Costa Rica 1569-1683. Anuario de Estudios Centroamericanos 9: 69-86.

Siisiäinen, Lauri. 2015. Foucault, Pastoral Power, and Optics. Critical Research on Religion 3: 233-49. [CrossRef]

Silva, Juan de. 1621. Advertencias Importantes acerca del Buen Gobierno y Administracion de las Indias, asi en lo Espiritual como en lo Temporal. Madrid: Viuda de Fernando Correa Montenegro.

Silva, Margarita. 1991. Estado y Política Liberal en Costa Rica: 1821-1940. San Jose: Editorial Universidad Estatal a Distancia.

Solorzano, Juan Carlos. 2002. Evangelización Franciscana y Resistencia Indígena: Dos Rebeliones en la frontera entre Costa Rica y Panamá (Cabagra, Térraba, 1761 y Bugaba, Alanje, 1787). Anuario de Estudios Centroamericanos 28: $57-88$.

Takács, Ádám. 2004. Between Theory and History: On the Interdisciplinary Practice in Michel Foucault's Work. MLN 119: 869-84. [CrossRef]

Thiel, Bernardo A. 1902. Monografia de la Poblacion de Costa Rica en el Siglo XIX. In Revista de Costa Rica en el Siglo XIX. Tomo Primero. San Jose: Tipografia Nacional, pp. 1-52.

Tierney, Thomas. 2004. Foucault on the case: The pastoral and juridical foundation of medical power. Journal of Medical Humanities 25: 271-90. [CrossRef] [PubMed]

Torres, Juan de, and Pedro de Betanzos. 1905. Doctrina Cristiana en Lengua Guatemalteca. In Doctrina Cristiana en Lengua Guatemalteca, Ordenada por el Reverendisimo Señor Don Francisco Marroquin. Edited by J. T. Medina. Santiago de Chile: Imprenta Elseveriana, pp. 21-84. First published 1556.

Velazquez, Maria. 2011. Los Cambios Político-Administrativos en la Diócesis de Nicaragua y Costa Rica. De las Reformas Borbónicas a la Independencia. Hispania Sacra 63: 569-93. [CrossRef]

Velazquez, Carmela. 2013. Abogados e intercesores para encontrar una buena muerte en la Costa Rica del siglo XVII. Diálogos Revista Electrónica de Historia 14: 195-220.

Villadsen, Kaspar. 2007. The Emergence of 'Neo-Philanthropy': A New Discursive Space in Welfare Policy? Acta Sociologica 50: 309-23. [CrossRef]

Wilde, Guillermo. 2009. Religión y Poder en las Misiones de Guaranies. Buenos Aires: Editorial SB.

Williams, Philips. 1989. The Catholic Church and Politics in Nicaragua and Costa Rica. Pittsburgh: Pittsburgh University Press.

Zavala-Pelayo, Edgar. 2016a. Colonial Pastoralism in Latin America: New Spain's Bio-political Religious Regime. Politics, Religion \& Ideology 17: 172-90. [CrossRef] 
Zavala-Pelayo, Edgar. 2016b. Another Pastoral Power: Spiritual Salvation through Worldly Integralism in Colonial Latin America. CAS Working Paper Series No. 1/2016, Center for Area Studies, Freie Universität Berlin.

Zavala-Pelayo, Edgar. 2017. Welfare governmentalities: pastoralism and parties' youth wings in Mexico. International Journal of Sociology and Social Policy 37: 808-22. [CrossRef] 